\title{
In vitro mineral nutrition of Curcuma longa L. affects production of volatile compounds in rhizomes after transfer to the greenhouse

\author{
Rabia F. El-Hawaz ${ }^{1 *}$, Mary H. Grace², Alan Janbey², Mary Ann Lila² and Jeffrey W. Adelberg ${ }^{1}$
}

\begin{abstract}
Background: Turmeric is a rich source of bioactive compounds useful in both medicine and cuisine. Mineral concentrations effects $\left(\mathrm{PO}_{4}{ }^{3-}, \mathrm{Ca}^{2+}, \mathrm{Mg}^{2+}\right.$, and $\left.\mathrm{KNO}_{3}\right)$ were tested during in vitro rhizome development on the ex vitro content of volatile constituents in rhizomes after 6 months in the greenhouse. A response surface method (D-optimal criteria) was repeated in both high and low-input fertilizer treatments. Control plants were grown on Murashige and Skoog (MS) medium, acclimatized in the greenhouse and grown in the field. The volatile constituents were investigated by GC-MS.

Results: The total content of volatiles was affected by fertilizer treatments, and in vitro treatment with $\mathrm{Ca}^{2+}$ and $\mathrm{KNO}_{3}$; but $\mathrm{PO}_{4}{ }^{3-}$ and $\mathrm{Mg}^{2+}$ had no significant effect. The content was higher in the high-input fertilizer treatments $(49.7 \pm 9 \mathrm{mg} / \mathrm{g}$ DM) with $4 \mathrm{mM} \mathrm{Ca}^{2+}, 60 \mathrm{mM} \mathrm{KNO}_{3}$ and $5 \mathrm{mM} \mathrm{NH}_{4}{ }^{+}$, than the low-input fertilizer (26.6 $\pm 9 \mathrm{mg} / \mathrm{g} \mathrm{DM}$ ), and the MS control $\left(15.28 \pm 2.7 \mathrm{mg} / \mathrm{g} \mathrm{DM} ; 3 \mathrm{mM} \mathrm{Ca}^{2+}, 20 \mathrm{mM} \mathrm{K}^{+}, 39 \mathrm{mM} \mathrm{NO}_{3}^{-}, 20 \mathrm{mM} \mathrm{NH}_{4}^{+}, 1.25 \mathrm{mM} \mathrm{PO}_{4}{ }^{3-}\right.$, and $\left.1.5 \mathrm{mM} \mathrm{Mg}^{2+}\right)$. The interaction of $\mathrm{Ca}^{2+}$ with $\mathrm{KNO}_{3}$ affected curcumenol isomer I and II, germacrone, isocurcumenol, and $\beta$-elemenone content. Increasing in vitro phosphate concentration to $6.25 \mathrm{mM}$ increased ex vitro neocurdione and methenolone contents.

Conclusion: These results show that minerals in the in vitro bioreactor medium during rhizome development affected biosynthesis of turmeric volatile components after transfer to the greenhouse six months later. The multi-factor design identified 1) nutrient regulation of specific components within unique phytochemical profile for Curcuma longa L. clone 35-1 and 2) the varied phytochemical profiles were maintained with integrity during the greenhouse growth in high fertility conditions.
\end{abstract}

Keywords: Bioreactor, Sesquiterpenes, GC-MS, Curcuma longa rhizome, Response surface methods, Fed-batch technique

\section{Background}

The variety of active ingredients has made turmeric, Curcuma longa an important medicinal herb, where the crude extract has many therapeutic properties such as anti-microbial, anti-inflammatory [1], parasiticidal activity [2], and hypoglycemic effects [3]. Volatile components derived from turmeric is a raw material of culinary, drug, and cosmetic industries. Following the phenolic components, curcuminoids; terpenoids are the second major bioactive constituents of Curcuma species. Terpenoids occur in a large variety of mono- and sesquiterpenes in Curcuma [4]. Their synthesis in leaves and the accumulation of

\footnotetext{
* Correspondence: rabiae@g.clemson.edu

${ }^{1}$ Department of Plant and Environmental Sciences, Clemson University,

Clemson, SC 29634, USA

Full list of author information is available at the end of the article
}

these compounds in plant tissue are affected by biotic and abiotic factors [5-8]. One of the problems associated with turmeric cultivation is that the content of curcumin, volatile components, and oleoresin vary with environmental factors that affect the economic value of the crop [9-11].

In vitro cultures were recognized as potential methods to produce secondary metabolites from plant cells, tissues, and organs for industry $[12,13]$. A large mass of plant material is a primary requirement to produce chemical compounds [14] and increasing the plant mass could be achieved by either using large vessels in "bioreactors" with liquid media $[15,16]$ or adding more initial plants mass with fed-batch supplementation during the culture cycle [17]. Commercial scale fed-batch bioreactors $(10,000$ to $20,000 \mathrm{~L}$ ) used to produce ginseng saponins from Panax ginseng root culture have achieved high yield [18]. 
Increasing in vitro propagated biomass in a field or greenhouse poses an alternative to upscale medicinal chemistry while maintaining quality attributes obtained in the bioreactor [19].

In vitro treatments including minerals, plant density, and fed-batch techniques (in vitro treatments) applied during 5 months of micropropagation in fed-batch bioreactors [17] effects the plant quality during the subsequent 6 months of greenhouse growth where rhizomes continue to attain mass. These effects include both the relative fresh mass gain of nursery plants [20] and the concentration of curcuminoids in the rhizome following a season of growth [19]. Following the previous work, this current paper investigated the effects of the in vitro treatments and fertilizer treatments on the GC-MS profile and content of C. longa rhizomes in the greenhouse by using a multi-factor response surface method (RSM).

\section{Methods}

\section{Plant materials}

Curcuma longa L35-1 rhizomes were provided by University of Arizona Southwest Center for Natural Products Research and Commercialization (UA Herbarium \#375,742, ARIZ) and used for the GC-MS analysis. The stock plants were initiated and propagated as described in [15].

\section{Micropropagation in bioreactor and fed-batch technique}

Turmeric rhizomes were grown on $40 \mathrm{~mL}$ modified MS media [21] in cylindrical glass jar $(180 \mathrm{~mL})$ with plant density (3, 6, 9 buds/vessel) for 3 cycles of 35 days per cycle then rhizomes were transferred to liquid modified MS media in bioreactor (2.5 L Liquid Lab Vessels, Southern Sun Inc., Hodges, SC, USA) with plant density $(6,12,18$ buds/vessel) [17]. The bioreactors were set on an intermittent immersion rocker system $[15,17,20]$ with one rotation per min to allow rhizomes dry and wet in the thin film liquid media (Fig. 1). Liquid MS media [21] was modified with $\left(\mathrm{NH}_{4}\right)_{2} \mathrm{SO}_{4},(5 \mathrm{mM})$, sucrose $(5 \% \mathrm{~m} / \mathrm{v})$, benzyladenine $(3 \mu \mathrm{M})$ [22] different combinations of in vitro factors (Additional file 1: Table S1), plant density and mineral concentrations, $\mathrm{PO}_{4}{ }^{3-}(1.25,3.75,6.25 \mathrm{mM}), \mathrm{Ca}^{2+}(3,6$, $9 \mathrm{mM}), \mathrm{Mg}^{2+}(1.5,3,4.5 \mathrm{mM})$, and $\mathrm{KNO}_{3}(20,40,60 \mathrm{mM})$, were selected by d-optimal criteria [17]. The set of experimental treatments was duplicated with each subset receiving two different fed-batch techniques, sucrose fed-batch (SF) and nutrient-sucrose fed-batch (NSF) applied twice during the 5 months culture (Fig. 2) and previously described by El-hawaz et al. [17]. The control plants were grown on $35 \mathrm{~mL}$ liquid MS medium [21] supplemented with $1 \mu \mathrm{M}$ benzyladenine and $3 \% w / v$ sucrose in a cylindrical glass jar $(180 \mathrm{~mL})$ with a Magenta B-cap closure (Magenta Crop, Chicago, IL, USA). Plants were subcultured at $23 \pm 2{ }^{\circ} \mathrm{C}$ for

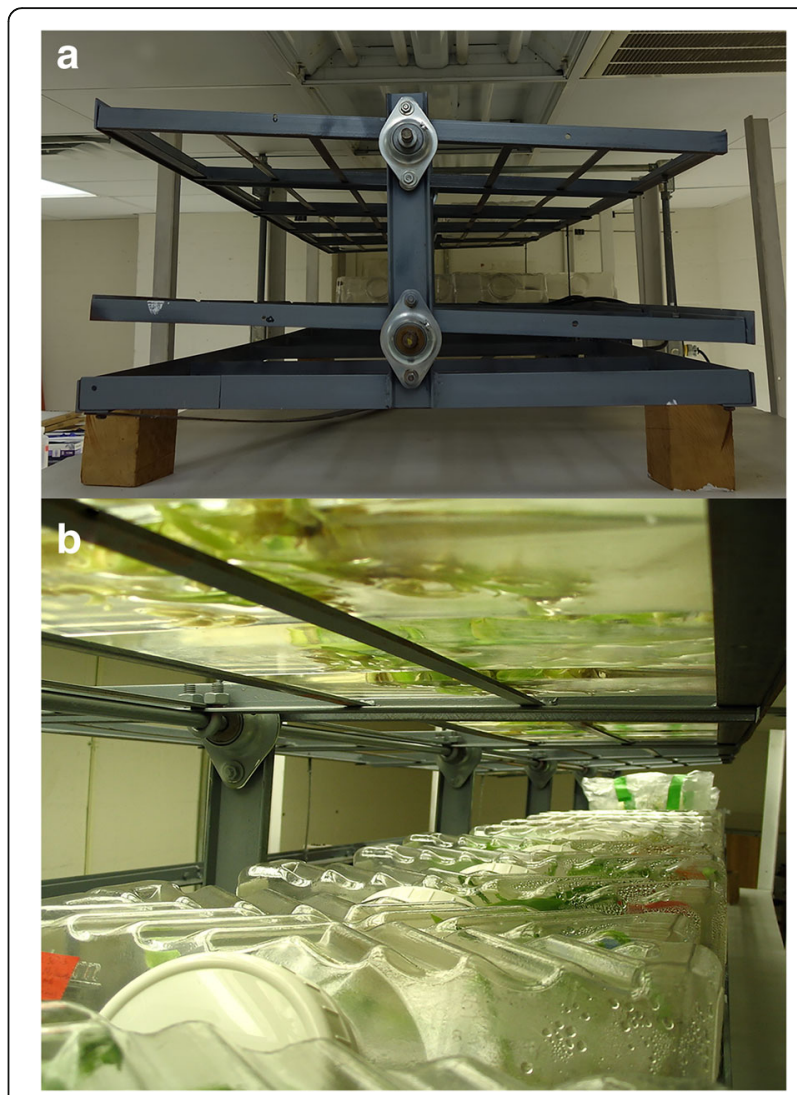

Fig. 1 The intermittent immersion rocker system. Periodic wetting and drying of tissue was created when the shelving was gently rocked by the motor (1 rpm) (a). The paired shelves were tilted once a minute. Viewing the underside of the vessels on the top shelf $(\mathbf{b})$, the shallow film of liquid medium barely covers the plant surface. Plants grow in the $2.5 \mathrm{~L}$ gaseous headspace of the vessels as seen on lower shelf

four 35 days cycles under $25-30 \mu \mathrm{mol} \mathrm{m} \mathrm{m}^{-2} \mathrm{~s}^{-1}$ photosynthetically active radiant for $16 \mathrm{~h}$ per day.

\section{Greenhouse growth}

Three explants transferred from each bioreactor were acclimatized under the mist (latitude $=34.67350$, longitude $=-82.83261 ; 60 \%$ shade cloth; mist cycle was $6 \mathrm{~s}$ on every 16 min during daylight hours) in Fafard $2 \mathrm{~B}$ (Canadian sphagnum peat moss, bark, perlite, vermiculite, wetting agent, and dolomitic limestone; Sun Gro Horticulture, Agawam, MA, USA) without starter fertilizer for SF subset, and with starter fertilizer for NSF subset for 21 days in the summer. In large pots $(8 \mathrm{~L}), \mathrm{SF}$ subset plant was placed in soilless mixture without any fertilizer considered the low-input treatment and NSF subset plant was placed in Fafard ${ }^{\circ}$ 2B with a complete charge of starter nutrients and considered as the high-input treatment. Pots were irrigated manually once each five days without fertilizer in the low-input treatment, and with $100 \mathrm{ppm} \mathrm{N}$ of (15-15-15 


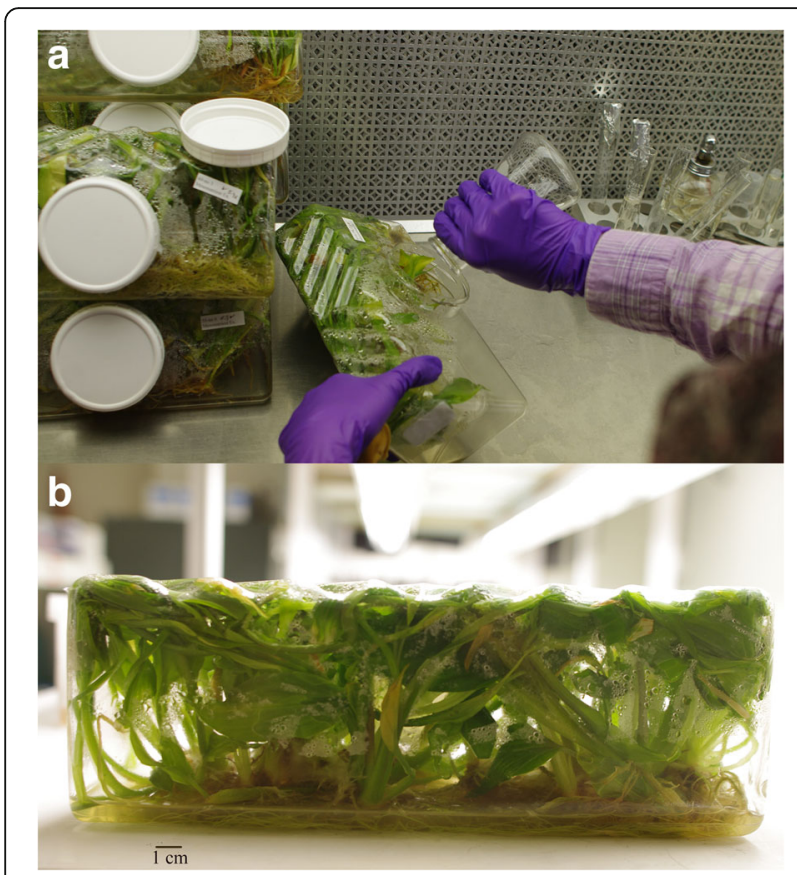

Fig. 2 The fed-batch technique of Curcuma longa $L$. in the bioreactor. a The fed-batch was applied twice during the 5 month growth period. The volume of water and sucrose concentration was returned to the set point in the sucrose fed-batch subset (SF), additional to that the mineral concentrations were returned to the set point in the nutrient-sucrose fed-batch subset (NSF). b Curcuma longa L. 35-1 filled the $2.5 \mathrm{~L}$ bioreactor during 5 months with nutrient supplementation

4Ca $2 \mathrm{Mg}$, Jack's professional LX. J.R. Peters, Inc.) in the high-input treatment [20]. Control plants were irrigated manually once each three days for two months then transferred to the field for three months. Control plants were set in the sun to dry before the harvesting. Harvested turmeric rhizomes were stored at $-80{ }^{\circ} \mathrm{C}$ until processing for GC-MS analysis.

\section{Sample preparation}

Rhizomes from treatments and control were frozen immediately after harvest and then samples for analysis were freeze-dried and ground to a fine powder. The turmeric powder from each sample $(0.5 \mathrm{~g} \times 3$ replicates $)$ was extracted by shaking with $10 \mathrm{~mL}$-hexane at $40{ }^{\circ} \mathrm{C}$ for $30 \mathrm{~min}$. The mixture was centrifuged at $4000 \mathrm{rpm}$ for another $10 \mathrm{~min}$ at $4{ }^{\circ} \mathrm{C}$. The clear supernatant was decanted into a conical flask containing about $0.5 \mathrm{~g}$ anhydrous sodium sulfate. The extraction procedure was repeated two more times by adding fresh n-hexane $(10 \mathrm{~mL})$ to the plant residue in the centrifuge tube. The collected hexane extracts were filtered (0.45 PTFE membrane filter), and evaporated under nitrogen $\left(\mathrm{N}_{2}\right)$ gas until complete dryness. Samples were prepared as $2.5 \mathrm{mg} / \mathrm{mL}$ in acetonitrile, and internal standard (oleic acid methyl ester) was added prior to GC-MS.

\section{GC-MS analysis}

Gas chromatography-mass spectrometry (GC-MS) analysis was carried out on an Agilent 7890A GC system attached to an Agilent 5975C MS detector. An Agilent HP-5 ms (30 m $\times 0.25 \mathrm{~mm}$ ID $0.25 \mu \mathrm{m}$ film thickness) was used for separation of volatile constituents using helium as a carrier gas at a flow rate of $1.2 \mathrm{~mL} / \mathrm{min}$. The oven temperature was programed at $60{ }^{\circ} \mathrm{C}$ for $5 \mathrm{~min}$, rising to $180{ }^{\circ} \mathrm{C}$ at $4{ }^{\circ} \mathrm{C} / \mathrm{min}$, then to $280{ }^{\circ} \mathrm{C}$ at $15{ }^{\circ} \mathrm{C} / \mathrm{min}$ with total run time of $60 \mathrm{~min}$. GC-MS parameters at electron impact (EI) mode included ionization voltage $70 \mathrm{eV}$, injector temperature of $250{ }^{\circ} \mathrm{C}$ with injector port set to split mode (1:10) and a mass scan range of $100-800 \mathrm{~m} / \mathrm{z}$. Identification of compounds was based on comparison of mass spectra with the GC-MS system data bank (NIST 05 library), comparison with published data, and retention indices.

\section{Measurements}

The fresh and dry mass of turmeric rhizomes after 6 months in the greenhouse and the control plants were measured. The concentration of the volatile components in the hexane extract was calculated based on their peak areas in the GC chromatogram in comparison to standard curve constructed with authentic reference curcumenone (Chem Faces, China). Results were expressed as mg curcumenone equivalent/g dried rhizome mass (DM). Percentage of each identified compound was measured based on its peak area relative to total area of the GC chromatogram. Measurements were carried out in triplicate and means were calculated. The concentrations of identified compounds were presented to identify the optimal in vitro formula that induced synthesis and accumulation in turmeric rhizomes. The predicted improvement (fold) was calculated by divide the concentration of each compound in the treatments on the average concentration of the control.

\section{Statistical analysis and experimental design}

The response surface method was used to model responses to five continuous factors at three levels using 32 design points with 3 additional points as true replicates that were selected by d-optimal criteria as described in [17]. The entire experiment was duplicated to apply two levels of the nominal factor (fed-batch technique). The fed-batch treatment in vitro was continued as fertilizer treatment in the greenhouse. The stepwise forward method was used to select the response surface models that presented in tables with the ANOVA summary, $R^{2}$, adjusted $R^{2}\left(R_{\mathrm{a}}^{2}\right)$, and $\mathrm{F}$ statistic at $P$-value. The software JMP version 13.0 
(SAS Inst., Cary, NC, USA) was used to make the data analysis and graphs.

\section{Results \\ Qualitative and relative-quantitative analysis of volatile constituents}

GC-MS analysis of the hexane extract showed that sesquiterpenes represented the major components of the GC-MS chromatogram of C. longa, comprising $>65 \%$ of total peak area. Identified sesquiterpenes ranged from non-oxygenated, mono-oxygenated and di-oxygenated chemical structures (Table 1). Two isomeric forms of curcumenol, tentatively identified here as curcumenol isomer I (10) and curcumenol isomer II (11), constituted the major components of the GC chromatogram, accounting for $28.68 \pm 0.91 \%$ and $17.96 \pm 0.69 \%$ of the total volatiles identified in the control plants, respectively (Table 1 ). Isocurcumenol (6) and curcumenone (9) $(\mathrm{m} / z 234$ $[\mathrm{M}]^{+}, \mathrm{C}_{15} \mathrm{H}_{22} \mathrm{O}_{2}$ ) were also identified at lower percentages (3.24 $\pm 0.14 \%$ and $2.10 \pm 0.22 \%$, respectively). Other identified compounds included germacrone (7), germacrene $D$ (2), germacrene A (3), germacrene B (4), $\beta$-elemene (1), $\beta$-elemenone (5), and neocurdione (8). Germacrene A (3), $\mathrm{B}(\mathbf{4})$, and D (2), were under the limit of quantitation in the low-input fertilizer rhizomes (Fig. 3) and the control. The last eluted peak (40.17 $\mathrm{min}$ ) was tentatively identified as methenolone (12) $\left([\mathrm{M}]^{+} 302, \mathrm{C}_{20} \mathrm{H}_{30} \mathrm{O}_{2}, 20.95 \pm 0.49 \%\right)$, a steroidal compound. The percentage of each identified compound in the GC-MS chromatogram based on peak area measurements was included in Table 1.

\section{Volatiles detected in all fertilizer treatments}

The total content of volatile compounds determined in the nutrient treated rhizome was significantly affected by fertilizer treatments in the greenhouse, in vitro concentration of $\mathrm{Ca}^{2+}$, and the interaction of $\mathrm{Ca}^{2+}$ and $\mathrm{KNO}_{3}$ (Table 2). The content was higher in the high-input fertilizer $(49.7 \pm 9 \mathrm{mg} / \mathrm{g} \mathrm{DM})$ than the low-input fertilizer plants $(26.6 \pm 9 \mathrm{mg} / \mathrm{g} \mathrm{DM})$ grown on in vitro media contained $4 \mathrm{mM} \mathrm{Ca}^{2+}, 60 \mathrm{mM} \mathrm{KNO}_{3}$, and $5 \mathrm{mM} \mathrm{NH}_{4}{ }^{+}$(Fig. 4) that suggested the more fertilizer in the greenhouse produced higher concentration volatile components in rhizomes. Both fertilizer treatments had greater concentrations of volatiles than the control $(15.28 \pm 2.68 \mathrm{mg} / \mathrm{g} \mathrm{DM})$ grown on MS medium contained $3 \mathrm{mM} \mathrm{Ca}^{2+}, 20 \mathrm{mM} \mathrm{K}^{+}$, $39 \mathrm{mM} \mathrm{NO}_{3}{ }^{-}$, and $20 \mathrm{mM} \mathrm{NH}_{4}{ }^{+}$[21]. The model terms in Table 2 shows the $\mathrm{Ca}^{2+}$ (3-9 $\mathrm{mM}$ ) had a negative effect on the volatile content but the optimal level of $\mathrm{Ca}^{2+}$ was higher than the lowest level $(3 \mathrm{mM})$. Interpretation of $\mathrm{Ca}^{2+}$ main effect was misleading because $\mathrm{Ca}^{2+}$ interacted significantly with $\mathrm{KNO}_{3}$ and must be qualified depending on $\mathrm{KNO}_{3}$ impact (Fig. 4). At $60 \mathrm{mM} \mathrm{KNO}$, the volatile content was maximized with little $\mathrm{Ca}^{2+}(4 \mathrm{mM})$. Reduced $\mathrm{KNO}_{3}$ to $20 \mathrm{mM}$ required more $\mathrm{Ca}^{2+}(6 \mathrm{mM})$ to increase the content of total volatiles in turmeric rhizome. The strength of the response surface model (RSM) over single factor experiments is its sensitivity to many second order effects. The maximum increase in volatile compounds was predicted from RSM model (similar to those in Table 2) derived from d-optimal selection of 35 treatment points from 243 experimental points in the design space. The predicted improvement of total volatile compounds in the high-input fertilizer rhizome was $6.5 \pm 1.2$ fold and in the low-input fertilizer rhizome was $3.5 \pm 1.2$ fold comparing to the control content.

Curcumenol isomers I (10) and II (11) were the major sesquiterpenes in MS control turmeric rhizomes (Table 1). In the nutrient treatments, the high-input fertilizer

Table 1 Compounds identified in the hexane extract of Curcuma longa L. 35-1 rhizomes by GC-MS

\begin{tabular}{llllllll}
\hline & Compound & $\mathrm{Rt}(\mathrm{min})$ & Molecular formula & Molecular weight & Control peak area\% & Low-input peak area\% & High-input peak area\% \\
\hline 1 & B-elemene & 20.83 & $\mathrm{C}_{15} \mathrm{H}_{24}$ & 204 & $0.85 \pm 0.14$ & $0.33 \pm 0.04$ & $1.96 \pm 0.40$ \\
2 & Germacrene D & 23.57 & $\mathrm{C}_{15} \mathrm{H}_{24}$ & 204 & $0.16 \pm 0.06$ & $0.07 \pm 0.01$ & $0.57 \pm 0.16$ \\
3 & Germacrene A & 24.3 & $\mathrm{C}_{15} \mathrm{H}_{24}$ & 204 & $0.14 \pm 0.04$ & $0.14 \pm 0.2$ & $0.36 \pm 0.08$ \\
4 & Germacrene B & 25.81 & $\mathrm{C}_{15} \mathrm{H}_{24}$ & 204 & $0.12 \pm 0.01$ & $0.10 \pm 0.02$ & $0.45 \pm 0.13$ \\
5 & -elemenone & 27.33 & $\mathrm{C}_{15} \mathrm{H}_{22} \mathrm{O}$ & 218 & $0.88 \pm 0.04$ & $1.04 \pm 0.23$ & $1.65 \pm 0.14$ \\
6 & Isocurcumenol & 27.97 & $\mathrm{C}_{15} \mathrm{H}_{22} \mathrm{O}_{2}$ & 234 & $3.24 \pm 0.14$ & $2.78 \pm 0.33$ & $3.21 \pm 0.20$ \\
7 & Germacrone & 29.81 & $\mathrm{C}_{15} \mathrm{H}_{22} \mathrm{O}$ & 218 & $4.46 \pm 1.51$ & $6.14 \pm 1.26$ & $9.64 \pm 0.72$ \\
8 & Neocurdione & 30.42 & $\mathrm{C}_{15} \mathrm{H}_{24} \mathrm{O}_{2}$ & 236 & $1.48 \pm 0.10$ & $1.08 \pm 0.28$ & $1.42 \pm 0.14$ \\
9 & Curcumenone & 30.85 & $\mathrm{C}_{15} \mathrm{H}_{22} \mathrm{O}_{2}$ & 234 & $2.10 \pm 0.22$ & $3.37 \pm 0.73$ & $2.16 \pm 0.40$ \\
10 & Curcumenol isomer I & 32.39 & $\mathrm{C}_{15} \mathrm{H}_{22} \mathrm{O}_{2}$ & 234 & $28.68 \pm 0.9$ & $25.94 \pm 2.8$ & $29.56 \pm 2.0$ \\
11 & Curcumenol isomer II & 33.75 & $\mathrm{C}_{15} \mathrm{H}_{22} \mathrm{O}_{2}$ & 234 & $17.96 \pm 0.7$ & $22.56 \pm 3.2$ & $21.82 \pm 2.9$ \\
12 & Methenolone & 40.14 & $\mathrm{C}_{20} \mathrm{H}_{30} \mathrm{O}_{2}$ & 302 & $20.95 \pm 0.5$ & $19.36 \pm 5.3$ & $8.56 \pm 2.75$ \\
& & & & $81.01 \pm 1.4$ & $82.93 \pm 3.6$ & $81.36 \pm 3.6$ \\
\hline
\end{tabular}

The volatile content in turmeric rhizomes of the control and the fertilizer treatments using GC-MS analysis. Percentages were measured based on peak area of each compound to total peak area of the GC chromatogram \pm standard deviation $(n=3)$ 


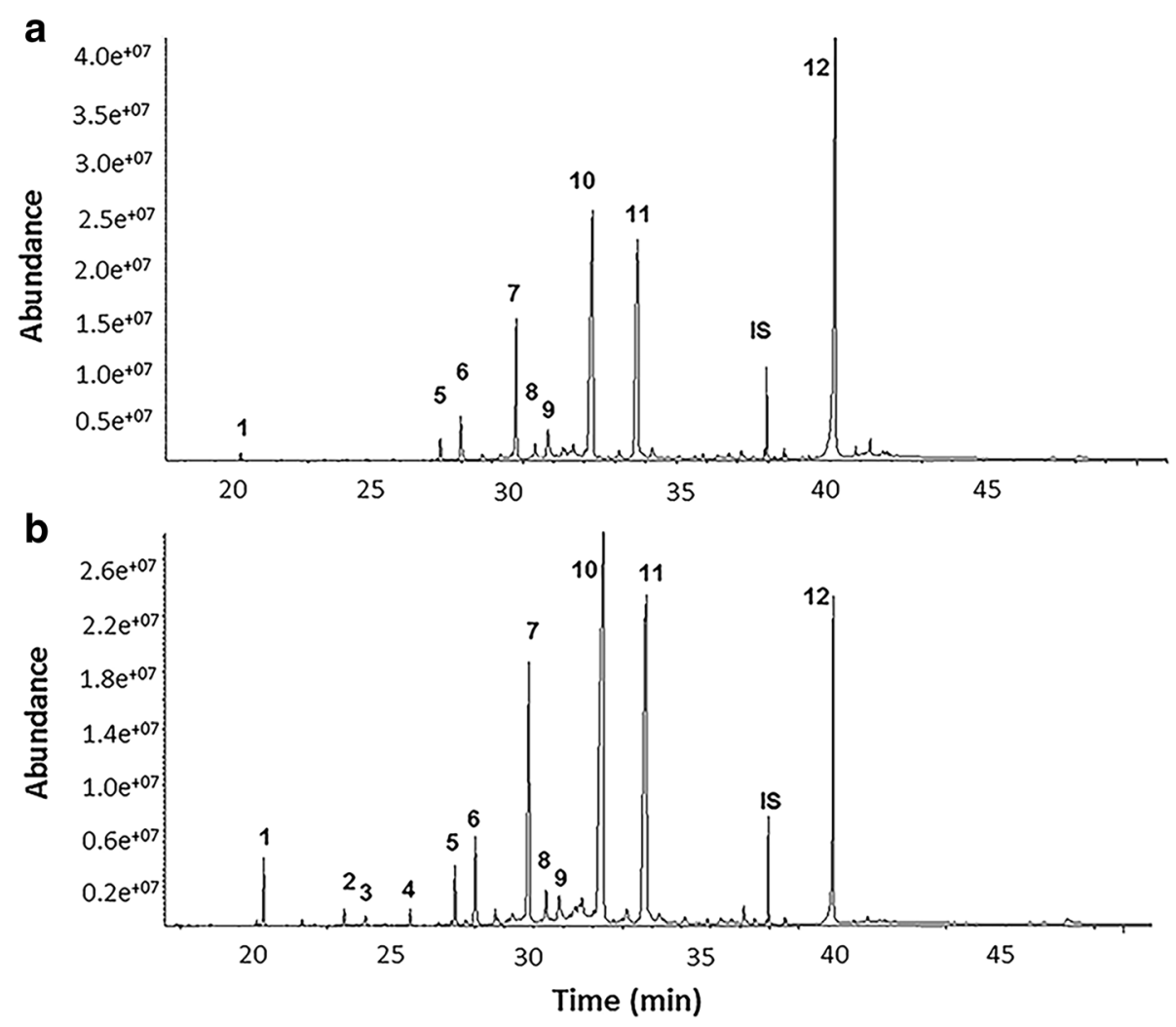

Fig. 3 GC-MS Chromatogram of Curcuma longa L. hexane extract. Representative GC-MS profile of Curcuma longa L. a Low-input fertilizer treatment SF 35 and (b) High-input fertilizer treatments NSF 35. Identification of peaks (1-12) was included in Table 1. IS=internal standard

Table 2 The significant terms of the response surface models of GC-MS analysis in Curcuma longa L.35-1 rhizome

\begin{tabular}{|c|c|c|c|c|c|c|c|c|c|c|}
\hline \multirow[b]{2}{*}{ Significant model terms } & \multicolumn{10}{|c|}{ Compounds $\left({ }^{a}\right)$} \\
\hline & (1) & (5) & (6) & (7) & (8) & (9) & (10) & $(11)$ & (12) & Total \\
\hline High-input Fertilizer & 0.0001 & 0.0001 & 0.0001 & 0.0001 & 0.0001 & 0.0001 & 0.0001 & 0.0001 & & 0.0001 \\
\hline $\mathrm{Ca}^{2+} \mathrm{mM}$ & 0.0267 & 0.0013 & 0.0059 & 0.0019 & 0.0478 & 0.0001 & 0.0042 & 0.0121 & 0.0395 & 0.0166 \\
\hline $\mathrm{KNO}_{3} \mathrm{mM}$ & & & & & & 0.0079 & 0.0200 & & & \\
\hline $\mathrm{Ca}^{2+} \times \mathrm{KNO}_{3} \mathrm{mM}$ & & 0.0312 & 0.0333 & 0.0104 & & 0.0070 & 0.001 & 0.0076 & & 0.0458 \\
\hline $\mathrm{Mg}^{2+} \mathrm{mM}$ & & & & & & 0.0073 & & & & \\
\hline $\mathrm{Mg}^{2+} \times \mathrm{KNO}_{3} \mathrm{mM}$ & & & & & & 0.0003 & & & 0.0208 & \\
\hline $\mathrm{Ca}^{2+} \times \mathrm{Mg}^{2+} \mathrm{mM}$ & & & & & & & 0.013 & & & \\
\hline High-input $\times$ Buds/Nessel & & & & & 0.0416 & & & & & \\
\hline High-input $\times \mathrm{PO}_{4}{ }^{3-} \mathrm{mM}$ & & & & & & 0.0083 & & & 0.0186 & \\
\hline High-input $\times \mathrm{Ca}^{2+} \mathrm{mM}$ & & & & & 0.0422 & & & & 0.0340 & \\
\hline High-input $\times \mathrm{KNO}_{3} \mathrm{mM}$ & & & & & 0.0494 & & & & & \\
\hline Buds/Nessel $\times \mathrm{PO}_{4}{ }^{3-} \mathrm{mM}$ & & & & & & 0.0378 & & & & \\
\hline$\left(\mathrm{PO}_{4}^{3-} \mathrm{mM}\right)^{2}$ & & & & & 0.0041 & 0.0060 & & & 0.0324 & \\
\hline$\left(\mathrm{Ca}^{2+} \mathrm{mM}\right)^{2}$ & 0.0101 & & & & & & & & & \\
\hline$R^{2}=$ & 0.804 & 0.785 & 0.687 & 0.785 & 0.772 & 0.688 & 0.771 & 0.701 & 0.448 & 0.666 \\
\hline
\end{tabular}

a(1) $\beta$-elemene, (5) $\beta$-elemenone, (6) isocurcumenol, (7) germacrone, (8) neocurdione, (9) curcumenone, (10) curcumenol isomer $I$, (11) curcumenol isomer $I I$, and (12) methenolone 


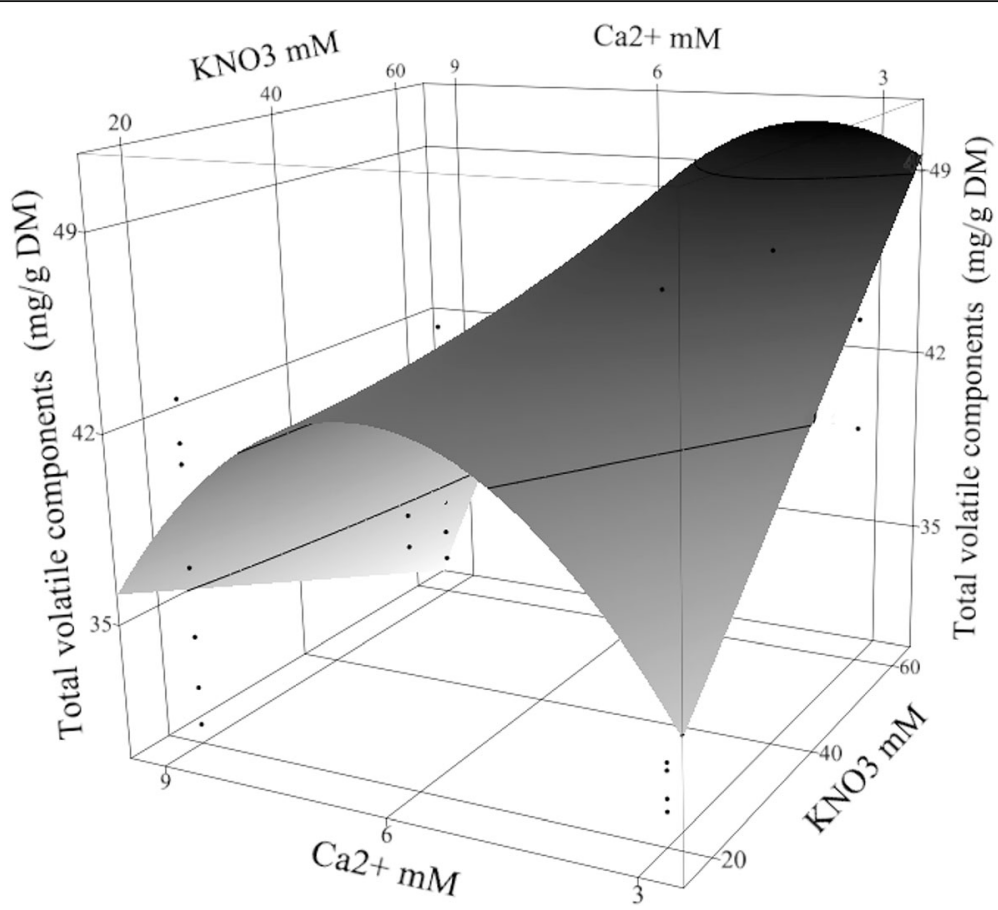

Fig. 4 Total content of volatiles under the high-input fertilizer treatment. Total volatile content $(\mathrm{mg} / \mathrm{g} \mathrm{DM})$ in high-input fertilized rhizome of Curcuma longa L. 35-1 was shown under the effect of in vitro $\mathrm{Ca}^{2+} \times \mathrm{KNO}_{3} \mathrm{mM}$ interaction. The contour surface and surface plus residual data points appeared on the response surface plot

treatments had the most significant effect followed by the interaction of $\mathrm{Ca}^{2+}$ and $\mathrm{KNO}_{3}$ (Table 2) on the content of curcumenol isomer I (10) and curcumenol isomer II (11). In the high-input fertilizer, the content of curcumenol isomer I (10) was the greatest at $28.05 \pm 3.14 \mathrm{mg} / \mathrm{g}$ $\mathrm{DM}$, and $16.48 \pm 3.14 \mathrm{mg} / \mathrm{g} \mathrm{DM}$ with the low-input fertilizer when the in vitro factors were $6.25 \mathrm{mM} \mathrm{PO}_{4}{ }^{3-}$, $3 \mathrm{mM} \mathrm{Ca}^{2+}, 1.5 \mathrm{mM} \mathrm{Mg}^{2+}$, and $60 \mathrm{mM} \mathrm{KNO}_{3}$. The control rhizome had low content of curcumenol isomers I (10) $(5.49 \pm 0.81 \mathrm{mg} / \mathrm{g} \mathrm{DM})$. The predicted improvement of curcumenol isomer I (10) was calculated similar to the total volatile components where the increase of curcumenol isomer I (10) in the high-input fertilizer rhizome was $10.2 \pm 1.1$ fold and in the low-input fertilizer rhizome was $6.0 \pm 1.1$ fold comparing to the control content.

Curcumenol isomer II (11) content was the greatest at $16.84 \pm 2.53 \mathrm{mg} / \mathrm{g} \mathrm{DM}$ of high-input fertilizer, and $9.96 \pm$ $2.53 \mathrm{mg} / \mathrm{g}$ DM with the low-input fertilizer when the in vitro factors set as $3 \mathrm{mM} \mathrm{Ca}^{2+}, 1.5 \mathrm{mM} \mathrm{Mg}^{2+}$, and $60 \mathrm{mM} \mathrm{KNO}_{3}$. However, the control rhizome content of curcumenol isomer II (11) was only $3.77 \pm 0.74 \mathrm{mg} / \mathrm{g}$ DM. Increasing $\mathrm{Ca}^{2+}$ concentration $(>3 \mathrm{mM})$ interacted with $60 \mathrm{mM} \mathrm{KNO}_{3}$ to reduce curcumenol isomers I (10) and II (11) contents (Fig. 5). At $60 \mathrm{mM} \mathrm{KNO}_{3}$, the lowest $\mathrm{Ca}^{2+}$ concentration $(3 \mathrm{mM})$ is increased curcumenol isomers I (10) and II (11) contents. The predicted improvement of curcumenol isomer II (11) was calculated similar to the total volatile components where the increase of curcumenol isomer II (11) in the dry high-input fertilizer rhizome was $13.9 \pm 1.5$ fold and in the low-input fertilizer rhizome was $11.3 \pm 1.5$ fold comparing to the control content.

High fertilizer treatments and reducing the divalent cation $\mathrm{Ca}^{2+}$ resulted in significant increases in the accumulation of germacrone (7), isocurcumenol (6), $\beta$-elemenone (5), and $\beta$-elemene (1) followed by the interaction effect of $\mathrm{Ca}^{2+}$ with $\mathrm{KNO}_{3}$ (Table 2). In the high-input fertilizer treatment, the content of germacrone (7) was maximized to $8.21 \pm 1.07 \mathrm{mg} / \mathrm{g} \mathrm{DM}$ with set of $3.5 \mathrm{mM} \mathrm{Ca}^{2+}$, $1.5 \mathrm{mM} \mathrm{Mg}^{2+}$, and $60 \mathrm{mM} \mathrm{KNO}_{3}$ (Fig. 6) and the content under the low-input fertilizer treatment (4.59 \pm $1.07 \mathrm{mg} / \mathrm{g} \mathrm{DM})$ was higher than the control $(1.05 \pm$ $0.10 \mathrm{mg} / \mathrm{g} \mathrm{DM})$. The predicted improvement of germacrone (7) was calculated similar to the total volatile components where the increased fold of germacrone (7) in high-input fertilizer was $15.6 \pm 2.0$ fold and in the low-input fertilizer was $8.7 \pm 2.0$ fold comparing to the control content. The content of isocurcumenol (6) was the greatest at $2.02 \pm 0.38 \mathrm{mg} / \mathrm{g} \mathrm{DM}$ with the high-input fertilizer and $1.04 \pm 0.38 \mathrm{mg} / \mathrm{g} \mathrm{DM}$ with the low-input fertilizer when the in vitro factors set as $4.3 \mathrm{mM} \mathrm{Ca}^{2+}$ and $60 \mathrm{mM} \mathrm{KNO}$. However, the control rhizome had $0.62 \pm$ $0.10 \mathrm{mg} / \mathrm{g} \mathrm{DM}$. The predicted improvement of isocurcumenol (6) was calculated similar to the total volatile 


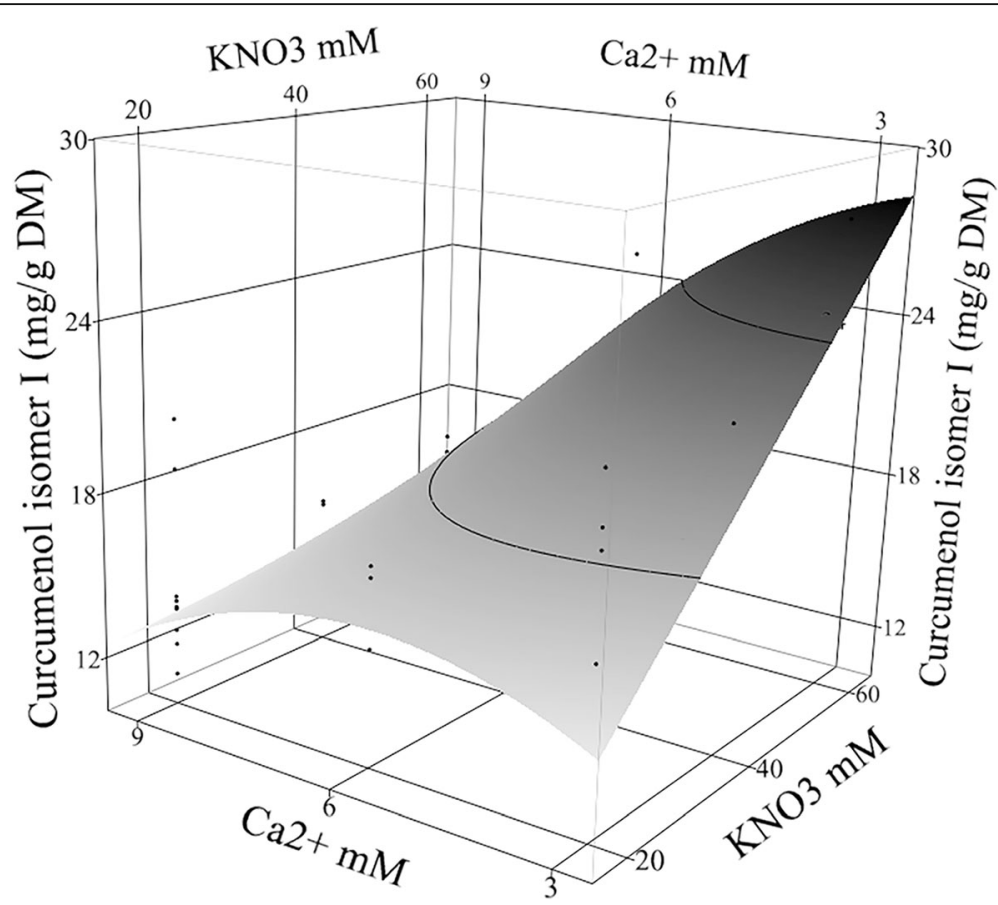

Fig. 5 Curcumenol isomer I content under the high-input fertilizer treatment. Curcumenol isomer I content (mg/g DM) in high-input fertilized rhizome of Curcuma longa L. 35-1 was shown under the effect of in vitro $\mathrm{Ca}^{2+} \times \mathrm{KNO}_{3} \mathrm{mM}$ interaction when the other factors were set as $6.25 \mathrm{mM} \mathrm{PO}_{4}{ }^{3-}$ and $1.5 \mathrm{mM} \mathrm{Mg}^{2+}$. The contour surface and surface plus residual data points appeared on the response surface plot

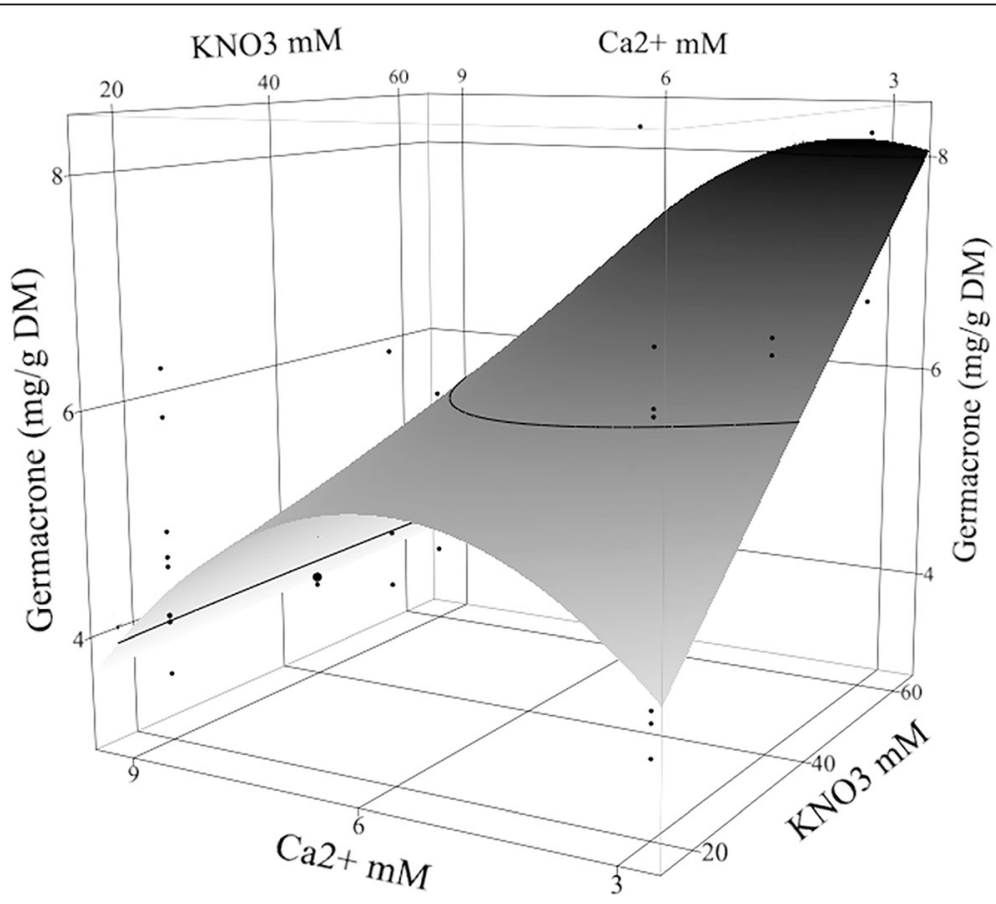

Fig. 6 Germacrone content under the high-input fertilizer treatment. Germacrone content (mg/g DM) in high-input fertilized rhizome of Curcuma longa $\mathrm{L}$. 35-1 was shown under the effect of in vitro $\mathrm{Ca}^{2+} \times \mathrm{KNO}_{3} \mathrm{mM}$ interaction when $\mathrm{Mg}^{2+}$ set as $1.5 \mathrm{mM}$. The contour surface and surface plus residual data points appeared on the response surface plot 
components where the increase of isocurcumenol (6) in high-input fertilizer was $6.6 \pm 1.2$ fold and in the low-input fertilizer was $3.4 \pm 1.2$ fold comparing to the control content. The content of $\beta$-elemenone (5) in the rhizome was the greatest at $1.08 \pm 0.17 \mathrm{mg} / \mathrm{g}$ DM with the high-input fertilizer when the in vitro factors set as 18 buds/vessel, $4.5 \mathrm{mM} \mathrm{Ca}^{2+}$, and $60 \mathrm{mM} \mathrm{KNO}_{3}$. In the low-input fertilizer, rhizome content $(0.41 \pm 0.17 \mathrm{mg} / \mathrm{g}$ DM) was higher than the control $(0.15 \pm 0.03 \mathrm{mg} / \mathrm{g} \mathrm{DM})$. The predicted improvement of $\beta$-elemenone (5) was calculated similar to the total volatile components where $\beta$-elemenone (5) increased in the high-input fertilizer to $14.0 \pm 2.2$ fold and in the low-input fertilizer to $5.3 \pm 2.2$ fold comparing to the control content. $\beta$-elemene (1) content was the greatest at $1.46 \pm$ $0.25 \mathrm{mg} / \mathrm{g}$ DM with the high-input fertilizer and $0.44 \pm$ $0.25 \mathrm{mg} / \mathrm{g} \mathrm{DM}$ with the low-input fertilizer when the in vitro factors set as 18 buds/vessel, $6.25 \mathrm{mM} \mathrm{PO}_{4}{ }^{3-}$, and $5.8 \mathrm{mM} \mathrm{Ca}^{2+}$. The control rhizome content was $0.11 \pm$ $0.0 .5 \mathrm{mg} / \mathrm{g}$ DM. The predicted improvement of $\beta$-elemene (1) was calculated similar to the total volatile components where the increase of $\beta$-elemene (1) in the high-input fertilizer rhizome was $26.5 \pm 4.7$ fold and in the low-input fertilizer rhizome was $8.0 \pm 4.7$ fold comparing to the control content.

The highest levels of $\mathrm{KNO}_{3}(60 \mathrm{mM})$ paired with $\mathrm{Ca}^{2+}$ concentration ranges from 3.5 to $5.8 \mathrm{mM}$ maximized the contents of germacrone (7), isocurcumenol (6), $\beta$-elemenone (5), and $\beta$-elemene (1) in the greenhouse rhizomes. The concentrations of $\mathrm{Ca}^{2+}, \mathrm{K}^{+}$, and $\mathrm{NO}_{3}{ }^{-}$were higher than standard MS medium (3, 19 and $40 \mathrm{mM}$, respectively; [22]) with $\mathrm{NH}_{4}{ }^{+}$was set at $5 \mathrm{mM}$ in our experimental medium (compared to $20 \mathrm{mM}$ in $\mathrm{MS}$ medium). At $20 \mathrm{mM} \mathrm{KNO}, 6 \mathrm{mM}$ of $\mathrm{Ca}^{2+}$ was required to increase the contents of the compounds in turmeric rhizomes. At $9 \mathrm{mM} \mathrm{Ca}^{2+}$, there was no significant difference between $\mathrm{KNO}_{3}$ concentrations (Fig. 6).

Neocurdione (8) content was significantly affected by the fertilizer treatments, the in vitro nutrient factors $\mathrm{PO}_{4}{ }^{3-}, \mathrm{Ca}^{2+}, \mathrm{KNO}_{3}$, and plant density (Table 2). With the high-input fertilizer treatments, the content of neocurdione (8) was maximized to $0.77 \pm 0.15 \mathrm{mg} / \mathrm{g}$ $\mathrm{DM}$ and $(0.34 \pm 0.15 \mathrm{mg} / \mathrm{g} \mathrm{DM}$ at the low-input fertilizer treatment) when the in vitro factors were set as 18 buds/vessel, $1.25 \mathrm{mM} \mathrm{PO}_{4}{ }^{3-}, 3 \mathrm{mM} \mathrm{Ca}^{2+}$, and $20 \mathrm{mM} \mathrm{KNO}$. The control rhizome had lower content than the fertilizer treatments $(0.23 \pm 0.03 \mathrm{mg} / \mathrm{g} \mathrm{DM})$. The predicted improvement of neocurdione (8) was calculated similar to the total volatile components where the increase of neocurdione (8) in the high-input fertilized was $6.6 \pm 1.3$ fold and in the low-input fertilized was $2.9 \pm 1.3$ fold comparing to the control content. High-input fertilizer increased the accumulation of neocurdione (8) with significant effect of high in vitro plant density
(18 bud/vessel), but all mineral concentrations in the micropropagation media had no significant effect on neocurdione (8) content. At the low-input fertilizer, mineral concentration significantly affected the content where rhizome's neocurdione (8) increased with low $\mathrm{PO}_{4}{ }^{3-}, \mathrm{Ca}^{2+}$, and $\mathrm{KNO}_{3}$ at any plant density. The accumulation of neocurdione (8) in the greenhouse rhizome required limited in vitro nutrient with increasing the initial plant density.

The steroid-methenolone (12) content was affected by the interaction of fertilizer treatments with $\mathrm{PO}_{4}{ }^{3-}$ and $\mathrm{Ca}^{2+}$, and the interaction of $\mathrm{Mg}^{2+}$ and $\mathrm{KNO}_{3}$ (Table 2). In the high-input fertilizer treatment, the content reached a maximum of $8.17 \pm 1.5 \mathrm{mg} / \mathrm{g}$ DM when in vitro factors were $6.25 \mathrm{mM} \mathrm{PO}_{4}{ }^{3-}, 6.2 \mathrm{mM}$ $\mathrm{Ca}^{2+}, 1.5 \mathrm{mM} \mathrm{Mg}{ }^{2+}$, and $60 \mathrm{mM} \mathrm{KNO}_{3}$ (Fig. 7). At high $\mathrm{KNO}_{3}(60 \mathrm{mM})$, the low $\mathrm{Mg}^{2+}(1.5 \mathrm{mM})$ promoted the accumulation of methenolone (12) in tumeric rhizomes. Increase $\mathrm{PO}_{4}{ }^{3-}$ increased methenolone (12) content. However, under the low-input fertilizer, lower $\mathrm{PO}_{4}{ }^{3-}$ increased the content. At $20 \mathrm{mM} \mathrm{KNO}_{3}$, the high $\mathrm{Mg}^{2+}(4.5 \mathrm{mM})$ promoted the accumulation of methenolone (12) to $7.04 \pm$ $1.5 \mathrm{mg} / \mathrm{g} \mathrm{DM}$ with $1.25 \mathrm{mM} \mathrm{PO}_{4}{ }^{3-}, 5.12 \mathrm{mM} \mathrm{Ca}^{2+}$, $4.5 \mathrm{mM} \mathrm{Mg}^{2+}$, and $20 \mathrm{mM} \mathrm{KNO}$. The control rhizome had lower content $(3.60 \pm 0.49 \mathrm{mg} / \mathrm{g} \mathrm{DM})$ than treatment rhizomes. The predicted improvement of methenolone (12) was calculated similar to the total volatile components where methenolone (12) increased in the high-input fertilizer rhizome to $4.5 \pm 0.8$ fold and in the low-input fertilizer rhizome to $3.0 \pm 0.8$ fold comparing to the control content.

Curcumenone (9) content was significantly influenced by many factors in this experiment including the fertilizer treatment, $\mathrm{Ca}^{2+}, \mathrm{KNO}_{3}$ and its interaction with the divalent cations $\mathrm{Ca}^{2+}$ and $\mathrm{Mg}^{2+}, \mathrm{PO}_{4}{ }^{3-}$ and its interaction with the fertilizer treatments, and plant density (Table 2). In both fertilizer treatments, the concentration reached a maximum of $2.5 \pm 0.24 \mathrm{mg} / \mathrm{g} \mathrm{DM}$ with in vitro factors 18 buds/vessel, $1.25 \mathrm{mM} \mathrm{PO}_{4}{ }^{3-}, 3 \mathrm{mM} \mathrm{Ca}^{2+}$, $1.5 \mathrm{mM} \mathrm{Mg}^{2+}$, and $60 \mathrm{mM} \mathrm{KNO}_{3}$ and that was greater than the control contents $(0.25 \pm 0.13 \mathrm{mg} / \mathrm{g} \mathrm{DM})$. The predicted improvement of curcumenone (9) was calculated similar to the total volatile components where curcumenone (9) increased in the high-input fertilized rhizome to $22.9 \pm 1.8$ fold and in the low-input fertilized rhizome to $20.4 \pm 1.8$ fold comparing to the control content. At $60 \mathrm{mM} \mathrm{KNO}_{3}$, the concentration of curcumenone (9) increased with decreasing $\mathrm{Mg}^{2+}$ to $1.5 \mathrm{mM}$. At $20 \mathrm{mM} \mathrm{KNO} 3, \mathrm{Mg}^{2+}$ had no significant effect on the content. Low $\mathrm{PO}_{4}{ }^{3-}(1.25 \mathrm{mM})$ increased curcumenone (9) accumulation with increasing plant density that reduced significantly the fertilizer treatments' effect. Increasing $\mathrm{PO}_{4}{ }^{3-}$ induced curcumenone (9) accumulation with the low plant density and high-input fertilizer. 


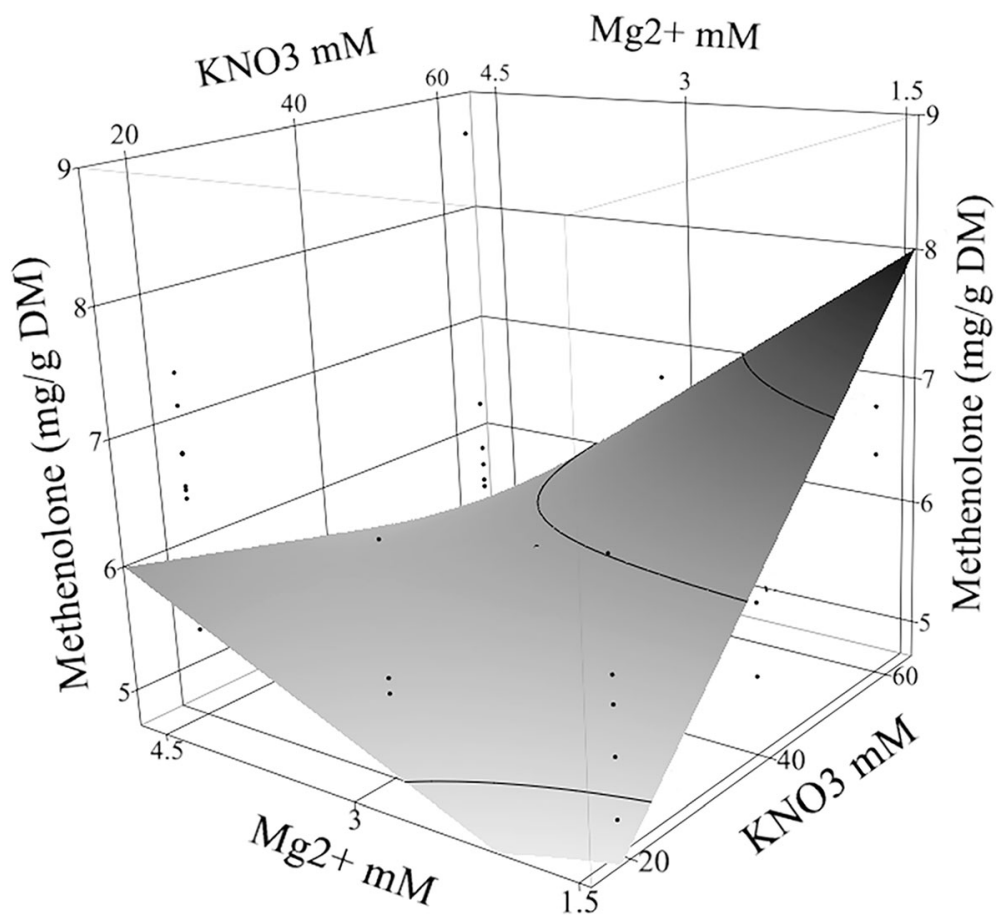

Fig. 7 Methenolone content under the high-input fertilizer treatment. Methenolone content (mg/g DM) in low-input fertilized rhizome was shown under the effect of in vitro $\mathrm{Mg}^{2+} \times \mathrm{KNO}_{3} \mathrm{mM}$ interaction when other factors set as $6.25 \mathrm{mM} \mathrm{PO}_{4}^{3-}$, and $6.2 \mathrm{mM} \mathrm{Ca}^{2+}$. The contour surface and surface plus residual data points appeared on the response surface plot

\section{Compounds detected in the high-input fertilizer treatment}

Germacrenes A (3), B (4), and D (2) were detected in the high-input fertilizer treatment but they were under the detection level in both low-input fertilizer treatment (Fig. 3) and the control rhizomes. In the high-input fertilizer treatment, $\mathrm{Ca}^{2+}$ affected significantly the content of germacrene D (2). The optimal level of $\mathrm{Ca}^{2+}(6 \mathrm{mM})$ maximized germacrene D (2) content to $0.38 \pm 0.15 \mathrm{mg} / \mathrm{g}$ $\mathrm{DM}$ when combined with the highest concentrations of $\mathrm{KNO}_{3}(60 \mathrm{mM})$ and $\mathrm{Mg}^{2+}(4.5 \mathrm{mM})$. The models of germacrene A (3) and germacrene B (4) were not significant and in vitro treatments had no effect on their concentrations.

\section{Association among multiple compound responses}

In the low-input fertilizer treatment, a significant correlation $(r=0.9)$ was found among the different sesquiterpene compounds in turmeric rhizome extract and sesquiterpene compounds significantly correlated $(r=0.7)$ with plant growth in the greenhouse (fresh and dry mass of leaves, rhizomes, and roots) as well in the control rhizomes. The volatile components were well correlated when the plant growth when was limited by nutrient input. On the other hand, volatile components concentrations in the high-input fertilizer treatment showed no significant correlation with plant growth in the greenhouse. An over abundance of nutrients caused overgrowth of leaves, rhizomes and roots that were not as efficient in producing the volatile components. The steroid methenolone (12) correlated only with curcumenone (9) $(r=0.6)$, but not plant growth.

Germacrenes A (3), B (4), and D (2) (Table 1) were under limited detection in the control and low-input treatment and only were quantified in the high input treatments. Concentrations of the minor compounds, germacrenes, in the high-input fertilizer rhizomes were significantly correlated $(r=0.9)$ with other sesquiterpenes, and $(r=0.5)$ with curcumenone (9). The overabundance of nutrient caused the production of germacrenes that were well correlated with the production of other sesquiterpenes.

Curcuminoids are the most important class of secondary compounds in turmeric. The content of volatile compounds correlated poorly with the curcuminoid compounds $(r=0.3)$ analyzed in a prior work [19]. Volatile compounds in turmeric rhizome extract likely have divergent pathways than curcuminoids compounds. Comparing the average percentage of each sesquiterpene compound in the control, low and high-input fertilizer treatments showed very strong correlation $(r=0.9)$ and when steroid compound (methenolone) was pulled out the correlation increased to $(r=0.98)$ showing that Curcuma longa L. 35-1 clone profile of sesquiterpenes similar to Table 1. 


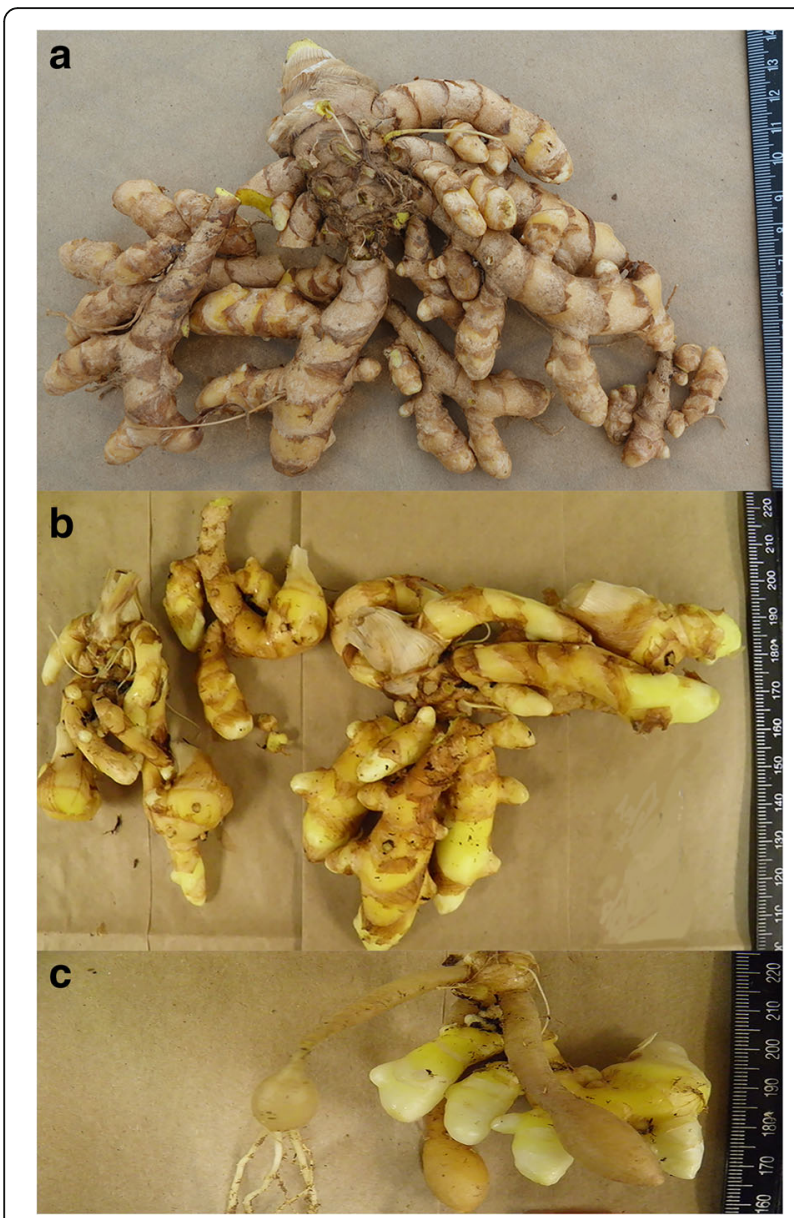

Fig. 8 Curcuma longa L. rhizomes. The harvested rhizome of Curcuma longa L. 35-1 (a) control, b high-input, and (c) low-input fertilizer treatments (experimental point 45) with in vitro factors set as 18 buds/vessel, $6.25 \mathrm{mM} \mathrm{PO}_{4}{ }^{3-}, 3 \mathrm{mM} \mathrm{Ca}^{2+}, 1.5 \mathrm{mM} \mathrm{Mg}^{2+}$, and $60 \mathrm{mM} \mathrm{KNO}_{3}$

\section{Volatile components were affected by fertility and the primary metabolism}

Considering the dry rhizome mass in both fertilizer treatments, the amount of the volatile compounds was greater in the high-input than the low-input fertilizer. The d-optimal design selection criteria used to produce these results reduced the number of tested points from 243 to 35 points, and one tested point (treatment 45) closest to the optimal was shown as an example (Fig. 8). The amount of volatiles produced was compared by multiplying the dry mass of rhizome by the concentration in the high-input / low-input fertilizer listed for each compound: $23.78 / 0.04 \mathrm{mg} \beta$-elemene, $16.60 / 0.29 \mathrm{mg}$ $\beta$-elemenone, $32.10 / 1.06 \mathrm{mg}$ isocurcumenol, $95.82 / 1.96 \mathrm{mg}$ germacrone, 9.29/0.30 mg neocurdione, 13.92/1.17 mg curcumenone, $291.71 / 9.95 \mathrm{mg}$ curcumenol isomer I, $224.63 / 9.07 \mathrm{mg}$ curcumenol isomer II, and 44.19/5.20 mg methenolone. The greater mass and concentration conferred in the high fertility treatment produced these overwhelming large differences. Primary metabolism (plant growth) and the production of secondary metabolites were simultaneously enhanced in these systems.

\section{Discussion}

A number of isomeric forms of sesquiterpenes, with the molecular formula $\mathrm{C}_{15} \mathrm{H}_{22} \mathrm{O}_{2}, \mathrm{~m} / z 234[\mathrm{M}]^{+}$, including curcumenol, epicurcumenol, isocurcumenol, procurcumenol and isoprocurcumenol, were previously identified in C. longa through isolation, NMR analysis, and other chemical and spectral determination methods [23, 24]. Germacrene A (3), B (4), and D (2) compounds are intermediate compounds in the biosynthesis metabolism [25] that might be caused the well correlation with other sesquiterpene concentrations in the high-input fertilizer treatment rhizome. Germacrene A is bound to sesquiterpene cyclase enzyme [26]. In our results they were found under detection level in the low-input fertilizer treatment and the control rhizomes that might due to their instability [25]. The steroid methenolone was previously identified in C. aeruginosa Roxb rhizome [27], and in the volatiles of Zingiber nimmonii J. Graham Dalzell [28], Alpinia purpurata Vieill [29], and. Equisetum giganteum L. [30].

Bisabolane-type sesquiterpenes were one of the main volatile components constituents of Curcuma species with ar-turmerone as the major compound [4]. Turmerones are known as the major sesquiterpenes in the volatile components of turmeric rhizome and the content varies from 40 to $60 \%$ [11]. The lack of the entire bisabolane-type sesquiterpenes, ar-turmerone, turmerone, curcumene, zingiberene, $\beta$-sesquiphellandrene, curlone, $\beta$-bisabolene, from our samples of Curcuma longa L. 35-1 profile (Table 1) may be due to the variation between genotypes. Genotypes had different profiles of volatile components and GC-MS distinguished two types of C. longa, the "yellow type" which contained mainly ar-tumerone, turmerone, culone, zingiberene, 2-carene, and $\beta$ - sesquiphellandrene, while the "red type" contained carvacrol, citral, methyleugenol, geraniol, menthol and caryophyllene oxide [31]. The clone in this experiment was not like either the "yellow" or "red" types.

The results showed how the clonal profile was impacted by the mineral nutrient and environment. The association among the volatile compounds in this genotypic profile was caused by the interaction of $\mathrm{KNO}_{3}$ and $\mathrm{Ca}^{2+}$ that had the most significant effect following fertilizer treatments on the accumulation of curcumenol isomers I and II, germacrone, isocurcumenol, and $\beta$-elemenone in turmeric rhizome. A similar interaction between $\mathrm{Ca}^{2+}$ and $\mathrm{KNO}_{3}$ increased the in vitro gain of turmeric fresh mass and plants with greater fresh mass were transferred to the greenhouse with $60 \mathrm{mM} \mathrm{KNO}_{3}$ and $3 \mathrm{mM} \mathrm{Ca}^{2+}$ [17]. This differs from the MS 1962 medium reported by all other 
groups working with turmeric [32] that contains $40 \mathrm{mM} \mathrm{K}^{+}$, $39 \mathrm{mM} \mathrm{NO}_{3}{ }^{-}, 20 \mathrm{mM} \mathrm{NH}_{4}{ }^{+}, 3 \mathrm{mM} \mathrm{Ca}{ }^{2+}, 1.5 \mathrm{mM} \mathrm{Mg}^{2+}$, and $1.25 \mathrm{mM} \mathrm{PO}_{4}{ }^{3-}$ [21], and MS was the medium we used for the control plants in this work. The invigoration of plant growth using the altered medium was coincident with the enhanced levels of sesquiterpenes. Studying nitrogen alone suggested a reduction in terpenoids and volatile content with increasing nitrogen supplement in the annual herbal plants [33] and Juniperus horizontalis [34]. Calcium involved in enzyme signal transductions in the cytosol [35] that might have a role in sesquiterpenes biosynthesis, especially as they are synthesized in the cytosol from the mevalonate pathway [36]. Calcium has been found regulate the antioxidant metabolism and water relations under the abiotic stress $[37,38]$ and decreased hydrogen peroxide and thiobarbutric acid [37, 39, 40]. Calcium was involved as a messenger in number of signal transduction pathways, although the calcium binding protein may interact directly with enzymes like sesquiterpene cyclase the most significant enzyme for sesquiterpene metabolism in plants [41]. The increases in the $\mathrm{Ca}^{2+}$ level in the nutrient solution increased the volatile components and sesquiterpene content in herbal plants, lemon grass, and bergamot and Japanese mint [42], and Chrysanthemum coronarium [43]. In tissue culture, $\mathrm{Ca}^{2+}$ enhanced the sesquiterpene production in Hyoscyamus muticus root [44]. In the field, applying $\mathrm{Ca}^{2+}$ increased carvacrol, $\gamma$-terpinene and $\beta$-bisabolene in Satureja hortensis [45], sesquiterpenes especially germacrene D in Chrysanthemum boreale [46].

However, the interaction of $\mathrm{KNO}_{3}$ and $\mathrm{Mg}^{2+}$ affected the content of curcumenone and methenolone. That might suggest an important role of the balance of the divalent cations $\mathrm{Ca}^{2+}$ and $\mathrm{Mg}^{2+}$ in the biosynthesis of the volatile components. The optimal concentrations of $\mathrm{K}^{+}$and $\mathrm{NO}_{3}{ }^{-}$in vitro were greater than concentrations specify in MS medium (20 and $40 \mathrm{mM}$ respectively). The optimal $\mathrm{K}^{+}$was 3 to $4 \times$ and the optimal $\mathrm{NO}_{3}{ }^{-}$was $1.5 \times$ greater than MS medium. However, previous work indicated $\mathrm{KNO}_{3}$ concentration was more important than $\mathrm{Ca}^{2+}$ and $\mathrm{Mg}^{2+}$ for turmeric growth, both in vitro and greenhouse growth $[17,47]$.

In the optimal growth media [20], $\mathrm{PO}_{4}{ }^{3-}$ was in the highest concentration $(6.25 \mathrm{mM})$ and that was related to increasing the supplement of sucrose during in vitro stage [17], which increased rhizome dry biomass in vitro [15]. Under the low-input fertilizer, methenolone concentration increased with $1.25 \mathrm{mM} \mathrm{PO}_{4}{ }^{3-}$ as well the concentration of curcumenone under both fertilizer treatments, which explained the low correlation between these compounds and growth. The reduction in $\mathrm{PO}_{4}{ }^{3-}$ from 1.5 to $0.5 \mathrm{mM}$ reduced the growth rate of Hyoscyamus muticus root and increased sesquiterpene yield in the bioreactors [48]. $\left[\mathrm{PO}_{4}{ }^{3-}\right]$ and $\left[\mathrm{Mg}^{2+}\right]$ significantly affected the content of methenolone and curcumenone
(Table 2) and that might cause the high correlation between these compounds. Mineral nutrients play a role in determining the concentration of secondary metabolites in plant where the content of volatile fraction in Achillea millefolium leaves altered based on elements availability in the hydroponic system [49].

The optimal contents of the volatile constituents in tumeric rhizome required the same mineral nutrient in vitro as the optimal growth, but we found that curcuminoids required different concentration of minerals to maximize the content. From our results, turmeric growth maximized under the high-input fertilizer treatments with 3.5-4 $\mathrm{mM} \mathrm{PO}_{4}{ }^{3-}, 5.7-6 \mathrm{mM} \mathrm{Ca}^{2+}$, and $60 \mathrm{mM} \mathrm{KNO}_{3}$ in vitro mineral nutrients that produced the greatest rhizome fresh mass [20]. However, the highest curcumin concentration was induced under the low-input fertilizer treatments with $6.25 \mathrm{mM} \mathrm{PO}_{4}{ }^{3-}, 3 \mathrm{mM} \mathrm{Ca}{ }^{2+}$, and $60 \mathrm{mM}$ $\mathrm{KNO}_{3}$ in vitro mineral nutrients [19]. Understanding the effect of mineral nutrition would allow determining the adequate supply of mineral in the micropropagation and the greenhouse systems to maximize the secondary metabolites production.

\section{Conclusion}

The content of the volatiles was impacted by prior in vitro treatments as well as by the amount of fertilizer applied during the greenhouse growth. The fertilizer treatments during the greenhouse growth increased the content of the volatiles in the rhizomes. High mineral concentration media with low ammonium concentration $(5 \mathrm{mM})$ were developed to increase the phytochemical production in turmeric rhizomes. The interaction of $\mathrm{KNO}_{3}$ and the divalent cation, $\mathrm{Ca}^{2+}$, play an important role in accumulation of sesquiterpenes in tumeric rhizome. The interaction of $\mathrm{Ca}^{2+}$ and $\mathrm{KNO}_{3}$ was similar in both fertilizer treatments in the greenhouse. At the highest $\mathrm{KNO}_{3}$ concentration in vitro, increasing $\mathrm{Ca}^{2+}$ concentration in vitro increased the total content germacrone (7), isocurcumenol (6), and $\beta$-elemenone (5) in turmeric rhizome, but the lowest concentration of $\mathrm{Ca}^{2+}$ increased curcumenol isomers I (10) and II (11), and curcumenone (9). The biochemical role of $\mathrm{Ca}^{2+}$ in the volatile compounds biosynthesis is still unclear and further investigations are needed. The increase of volatile content in turmeric rhizome can be done without diminishing curcuminoid production. The total volatile content was correlated to the primary metabolism, growth; which is dissimilar to curcuminoid accumulation in rhizomes. Phytochemical concentrations were multiplied significantly by primary metabolism in the ex vitro growth of the rhizome during greenhouse culture. The multifactor design, response surface method (RSM), elucidated important mineral factors that affected the subsequent accumulation of secondary metabolites 6 months after applying the treatments. The multi-factor approach 
defined (1) the unique chemo types for C. longa L. 35-1 and (2) the association between volatile and primary metabolism.

\section{Additional file}

Additional file 1: Turmeric volatile constituents data. (XLSX $26 \mathrm{~kb}$ )

\section{Abbreviations}

DM: The dry mass of rhizome; GC-MS: Gas chromatography-mass spectrometry; MS: Murashige and Skoog medium; RSM: Response surface method

\section{Availability of data and materials}

The data that generated in this study are included in this published article under the name (tumeric volatile constituents' data) in excel formats [file].

\section{Authors' contributions}

RE and JA conducted the micropropagation and the greenhouse growth experiments, analyzed the data, and interpreted the results. JA designed the experiment. MG, AJ, and MAL prepared the samples and analyzed the volatiles. RE drafted the manuscript. JA, MAL, MG reviewed and edited the manuscript. All authors read and approved the final manuscript.

\section{Ethics approval and consent to participate}

Not applicable.

\section{Consent for publication}

Not applicable.

\section{Competing interests}

The authors declare that they have no competing interests

\section{Publisher's Note}

Springer Nature remains neutral with regard to jurisdictional claims in published maps and institutional affiliations.

\section{Author details}

'Department of Plant and Environmental Sciences, Clemson University, Clemson, SC 29634, USA. ${ }^{2}$ Plants for Human Health Institute, North Carolina State University, Kannapolis, NC 28081, USA.

Received: 11 December 2017 Accepted: 7 June 2018

Published online: 18 June 2018

\section{References}

1. Srimal RC. Turmeric: a brief review of medicinal properties. Fitoterapia. 1994; 68:483-93.

2. Haddad M, Sauvain M, Deharo E. Curcuma as a parasiticidal agent: a review. Planta Med. 2011;77:672-8

3. Honda S, Aoki F, Tanaka H, Kishida H, Nishiyama T, Okada S, Matsumoto I, Abe K, Mae T. Effects of ingested turmeric oleoresin on glucose and lipid metabolisms in obese diabetic mice: a DNA microarray study. J Agric Food Chem. 2006;54:9055-62.

4. Nahar L, Sarker S. Phytochemistry of the genus Curcuma. In: Ravindran P, Nirmal Babu K, Sivaraman K, editors. Turmeric the genus Curcuma. Boca Raton: CRC press; 2007. p. 71-106.

5. Dixit D, Srivastava NK. Distribution of photosynthetically fixed ${ }^{14} \mathrm{CO}_{2}$ into curcumin and essential oil in relation to primary metabolites in developing turmeric (Curcuma longa) leaves. Plant Sci. 2000;152(2):165-71.

6. Dixit D, Srivastava NK, Sharma S. Boron deficiency induced changes in translocation of ${ }^{14} \mathrm{CO}_{2}$-photosynthate into primary metabolites in relation to essential oil and curcumin accumulation in turmeric (Curcuma longa L.). Photosynthetica. 2002;40(1):109-13.

7. Morison JIL, Lawlor DW. Interactions between increasing $\mathrm{CO}_{2}$ concentration and temperature on plant growth. Plant Cell Environ. 1999:22:659-82.

8. Srivastava $\mathrm{K}$, Sharma $\mathrm{S}$, Misra A. Influence of $\mathrm{Zn}$ on allocation of leaf-assimilated ${ }^{14} \mathrm{CO}_{2}$ into primary metabolites in relation to production of essential oil and curcumin in turmeric (Curcuma longa L.). W. J. A. Sci. 2006;2:201-7.
9. Mohanty DC. Genetic variability and inter relationship among rhizome yield and yield components in turmeric. Andhra Agric J. 1979;26:77-80.

10. Rama Rao M, Rao DVR. Genetic resources of turmeric, advances in horticulture. In: Chadha KL, Rethinam P, editors. Plantation and Spice Crops. New Delhi: Malhotra Publishing House; 1994. p. 1.

11. Sandeep S, Kuanar A, Akbar A, Kara B, Das S, Mishra A, Sial P, Naik P, Nayak S, Mohanty S. Agroclimatic zone based metabolic profiling of turmeric (Curcuma Longa L.) for phytochemical yield optimization. Ind Crop Prod. 2016;85:229-40.

12. Sajc $L$, Grubisic D, Vunjak-Novako G. Bioreactors for plant engineering: an outlook for further research. Biochem Engin J. 2000;4:89-99.

13. Yeoman MM, Yeoman CL. Manipulating secondary metabolism in cultured plant cells. New Phytol. 1996;134(4):553-69.

14. Weathers PJ, Towler MJ, Xu J. Bench to batch: advances in plant cell culture for producing useful products. Appl Microbiol Biotechnol. 2010;85:1339-51. https://doi.org/10.1007/s00253-009-2354-4.

15. Adelberg J, Cousins M. Thin films of liquid media for heterotrophic growth and storage organ development: turmeric (Curcuma longa) as a model plant. Hortscience. 2006;41(3):539-42.

16. Adelberg J, Fári G. Applied physiology and practical bioreactors for plant propagation. Propag Ornam Plants. 2010;10(4):205-19.

17. El-Hawaz RF, Bridges WC, Adelberg JW. In vitro growth of Curcuma longa L. In response to five mineral elements and plant density in fed-batch culture systems. PLoS One. 2015;10(4):e01 18912. https://doi.org/10.1371/journal.pone.0118912.

18. Choi YE, Kim YS, Paek KY. Types and designs of bioreactors for hairy root culture. In: Gupta SD, Ibaraki Y, editors. Plant tissue culture engineering. The Netherlands: Springer; 2008. p. 161-72.

19. El-Hawaz R, Tharayil N, Bridges W, Adelberg J. Mineral nutrition of Curcuma longa $\mathrm{L}$. in bioreactors affects subsequent development of curcuminoids following transfer to the greenhouse. Ind Crop Prod. 2016;83:186-93. https://doi.org/10.1016/j.indcrop.2015.11.063.

20. El-Hawaz RF, Bridges WC, Adelberg JW. Nutrition in fed-batch bioreactors affects subsequent size and productivity of turmeric during six months in greenhouse. Acta Hort. 2016;(1113):59-65. https://doi.org/10.17660/ ActaHortic.2016.1113.8.

21. Murashige T, Skoog F. A revised medium for rapid growth and bioassays with tobacco tissue cultures. Physiol Plant. 1962;15(3):473-97. https://doi. org/10.1111/j.1399-3054.1962.tb08052.x.

22. Adelberg J, Driesse T, Halloran S, Bridges W. Relationships between nutrients and plant density in liquid media during micropropagation and acclimatization of turmeric. In Vitro Cell Dev. Biol. Plant. 2013;49:724-36. https://doi.org/10.1007/s11627-013-9576-y.

23. He XG, Lin LZ, Lian LZ, Lindenmaier M. Liquid chromatography-electrospray mass spectrometric analysis of curcuminoids and sesquiterpenoids in turmeric (Curcuma longa). J Chromatograph A. 1998;818(1):127-32.

24. Oshiro M, Kuroyanagi M, Ueno A. Structures of sesquiterpenes from Curcuma longa. Phytochemistry. 1990;29(7):2201-5.

25. de Kraker JW, Franssen MC, de Groot A, König WA, Bouwmeester HJ. (+)-Germacrene a biosynthesis: the committed step in the biosynthesis of bitter sesquiterpene lactones in chicory. Plant Physiol. 1998:117(4):1381-92.

26. Cane DE, Tsantrizos YS. Aristolochene synthase. Elucidation of the cryptic germacrene a synthase activity using the anomalous substrate dihydrofarnesyl diphosphate. J. Ameri. Chem Soci. 1996;1 18(42):10037-40.

27. Simoh S, Zainal A. Chemical profiling of Curcuma aeruginosa Roxb. Rhizome using different techniques of solvent extraction. APJTB. 2015;5(5):412-41.

28. Finose A, Gopalakrishnan V. Phytochemical screening, HPTLC and GC-MS profiling in the rhizomes of Zingiber nimmonii J. Graham Dalzell. Asian J. Pharm. Clin Res. 2014:7(2):54-7.

29. Oirere EK, Anusooriya P, Raj CA, Gopalakrishnan VK. Phytochemical analysis of $n$-hexane leaf extract of Alpinia purpurata (Vielell.) K. Schum using UV-VIS, FTIR and GC-MS. Int. J Pharm Pharm Sci. 2015;7(8):387-9.

30. Michielin EMZ, Brescianib LFV, Danielskic L, Yunesb RA, Ferreira SRS. Composition profile of horsetail (Equisetum giganteum L.) oleoresin comparing SFE and organic solvents extraction. J Supercrit Fluids. 2005;33:131-8,

31. Chowdhury JU, Nadi NC, Bhuiyan MNI, Mobarok MH. Essential oil constituents of the rhizomes of two types of Curcuma longa of Bangladesh. Bangladesh. J Sci Ind Res. 2008;43(2):259-66.

32. Ravindran PN, Nirmal Babu K, Sivaraman K. Turmeric the genus Curcuma. Boca Raton: CRC Press; 2007

33. Mihaliak CA, Lincoln DE. Growth pattern and carbon allocation to volatile leaf terpenes under nitrogen-limiting conditions. Oecologia. 1985;66:423-6. 
34. Waring RH, McDoanld AJS, Larsson S, Ericsson T, Wiren A, Arwidsson E, Ericsson A, Lohammar T. Differences in chemical composition of plants grown at constant relative growth rate with stable mineral nutrition. Oecologia. 1985:66:157-60.

35. Siddiqui MH, Al-Whaibi MH, Sakran AM, Basalah MO, Ali HM. Effect of calcium and potassium on antioxidant system of Vicia faba L. under cadmium stress. Int J Mol Sci. 2012;13:6604-19. https://doi.org/10.3390/ijms13066604.

36. Zorrig W, Shahzad Z, Abdelly C, Berthomieu P. Calcium enhances cadmium tolerance and decreases cadmium accumulation in lettuce (Lactuca sativa). Afr J Biotechnol. 2012;11(34):8441-8. https://doi.org/10.5897/AJB11.2343.

37. Tian S, Lu L, Zhang J, Wang K, Brown P, et al. Calcium protects roots of Sedum alfredii $\mathrm{H}$. Against cadmium-induced oxidative stress. Chemosphere. 2011;84:63-9. https://doi.org/10.1016/..chemosphere.2011.02.054.

38. Taiz L, Zeiger E. Plant physiology. 4th ed. Sunderland: Sinauer Associates Inc: 2006.

39. Aharoni A, Jongsma MA, Kim T, Ri M, Giri P, Vertappen FWA, Schwab W, Bouwmeester $\mathrm{H}$. Metabolic engineering of terpenoid biosynthesis in plants. Phytochem Rev. 2006;5:49-58.

40. Van Huylenbroeck JM, Piqueras A, Debergh PC. The evolution of photosynthetic capacity and the antioxidant enzymatic system during acclimatization of micropropagated Calathea plants. Plant Sci. 2000;155:59-66.

41. Vögeli U, Vögeli-Lange R, Chappell J. Inhibition of phytoalexin biosynthesis in elicitor-treated tobacco cell-suspension cultures by calcium/calmodulin antagonists. Plant Physiol. 1992;100(3):1369-76.

42. Kothari SK, Singh V, Singh K. Effect of rates and methods of phosphorus application on herb and oil yields and nutrient concentrations in Japanese mint (Mentha arevensis L.). J Agric Sci. 1987;108:691-3.

43. Supanjani TARM, Yang MS, Han HS. Lee KD. Calcium effects on yield, mineral uptake and terpene components of hydroponic Chrysanthemum coronarium L. res. Agric.\& biol. Sci. 2005;1(2):146-51.

44. Curtis WR, Wang P, Humphrey A. Role of calcium and differentiation in enhanced sesquiterpene elicitation from calcium alginate-immobilized plant tissue. Enzym Microb Technol. 1995;17(6):554-7.

45. Mumivand H, Babalar M, Hadian J, Fakhr-Tabatabaei M. Plant growth and essential oil content and composition of Satureja hortensis L. cv. Saturn in response to calcium carbonate and nitrogen application rates. J. Med. Plant Res. 2011;5(10):1859-66.

46. Lee KD. Yang MS. changes in mineral and terpene concentration following calcium fertilization of Chrysanthemum boreale. M. Res J Agric\& Biol Sci. 2005;1(3):222-6

47. Adelberg J, Driesse T, Halloran S, Bridges W. Relationships between nutrients and plant density in liquid media during micropropagation and acclimatization of turmeric. In Vitro Cell Dev Biol Plant. 2013;49:724-36. https://doi.org/10.1007/s11627-013-9576-y.

48. Dunlop DS, Curtis WR. Synergistic response of plant hairy-root cultures to phosphate limitation and fungal elicitation. Biotechnol Prog. 1991;7(5):434-8.

49. Alvarenga I, Boldrin P, Pacheco V, Silva S, Bertolucci S, Pinto J. Effects on growth, essential oil content and composition of the volatile fraction of Achillea millefolium L. cultivated in hydroponic systems deficient in macro- and microelements. Scientia Hort. 2015;197:329-38.

\section{Ready to submit your research? Choose BMC and benefit from:}

- fast, convenient online submission

- thorough peer review by experienced researchers in your field

- rapid publication on acceptance

- support for research data, including large and complex data types

- gold Open Access which fosters wider collaboration and increased citations

- maximum visibility for your research: over $100 \mathrm{M}$ website views per year

At BMC, research is always in progress.

Learn more biomedcentral.com/submissions 